\title{
KEARIFAN LOKAL UPACARA LARUNGAN TELAGA NGEBEL DALAM MEMBANGUN HARMONISASI SOSIAL
}

\author{
Try Agung Handaya Putra \\ FKIP Universitas Muhammadiyah Malang, Indonesia \\ Email: tryagunghandaya@gmail.com
}

\begin{abstract}
ABSTRAK
Penelitian ini bertujuan untuk mendeskripsikan: (1) partisipasi masyarakat dalam upacara larungan, (2) kearifan lokal upacara larungan dapat mewujudkan harmonisasi sosial masyarakat, (3) peran pemerintah desa dalam mencegah konflik dengan memanfaatkan kearifan lokal upacara larungan. Penelitian ini menggunakan penelitian kualitatif dengan metode deskriptif. Sumber data yang digunakan adalah Pemerintah Desa Ngebel, tokoh masyarakat Desa Ngebel dan masyarakat Desa Ngebel. Pengumpulan data dikumpulkan dengan teknik wawancara, dokumentasi dan observasi. Teknik analisis data yang digunakan adalah data reduction, data display, dan conclusion drawing/verification. Hasil penelitian menunjukkan (1) partisipasi masyarakat Desa Ngebel dalam upacara larungan tergolong aktif dibuktikan dengan keikutsertaan masyarakat dalam rangkain kegiatan yang sudah disusun oleh panitia pelaksana; (2) nilai-nilai kearifan lokal yang terkandung dalam upacara larungan antara lain: nilai religi, nilai hiburan, nilai kekerabatan, nilai keindahan dan nilai simbolik. Kearifan lokal dalam upacara larungan memiliki kekuatan untuk menumbuhkan rasa persatuan sehingga membuat persaudaraan masyarakat semakin kuat yang menjadikan masyarakat dapat hidup damai dan harmonis; (3) nilai kearifan lokal dalam upacara larungan yang menjunjung semangat persatuan dimanfaatkan pemerintah desa dan stakeholders dalam menyelesaikan konflik yang timbul di masyarakat.
\end{abstract}

Kata Kunci: Kearifan Lokal; Upacara Larungan; Harmonisasi

\begin{abstract}
This study aims to describe: (1) community participation in upacara larungan, (2) local wisdom of upacara larungan can realize social harmonization of society, (3) role of village government in preventing conflict by exploiting local wisdom of upacara larungan. This research uses qualitative research with descriptive method. The data sources used are Ngebel Village Government, Ngebel village community leaders and Ngebel Village community. Data collection was collected by interview, documentation and observation techniques. Data analysis techniques used are data reduction, display data, and conclusion drawing/verification. The results of the study showed (1) the participation of Ngebel Village communities in the upacara larungan is classified as actively evidenced by the participation of the community in the series of activities that have been prepared by the organizing committe; (2) the values of local wisdom contained in the upacara larungan include: religious value, entertainmen value, kinship value, beauty value and siymbolic value. Local wisdom in the upacara larungan has the power to foster a sense of unity that makes the community fraternity stronger that makes the people can live in peace and harmony; (3) the value of local wisdom in the upacara larungan that upholds the spirit of unity utilized by the village government and stakeholders in resolving conflicts arising in the community.
\end{abstract}

Keywords: Local Wisdom; Upacara Larungan; Harmonization

\section{PENDAHULUAN}

Negara Indonesia terdiri atas berbagai pulau. Setiap pulau didiami oleh suku-suku bangsa yang mempunyai corak kehidupan berbeda dengan suku bangsa yang lain. Perbedaan tersebut menjadikan Indonesia mempunyai berbagai ragam etnik yang masing-masing etnik melahirkan budaya daerah. Keanekaragaman budaya daerah berupa kesenian, adat istiadat, tradisi, dan upacara-upacara ritual. 
Mulyadi(Suminar, 2012) menyatakan bahwa tradisi dan upacara adat merupakan salah satu bagian dari kebudayaan daerah yang dijaga kelestariannya oleh masyarakat pendukungnya. Salah satu perwujudan tradisi adalah upacara adat. Upacara adat tersebut merupakan warisan dari nenek moyang secara turun-temurun, dari generasi ke generasi yang di dalamnya terkandung nilai-nilai historis, moral, dan kultural yang tertuang serta terangkum dalam satu kebudayaan yang utuh. Sejarah tradisi dan upacara adat tercipta dalam perjalanan waktu yang panjang dan proses yang lama dari pendirinya atau cikal bakal. Pengertian cikal bakal adalah sekelompok orang yang pertama kali mendiami suatu kawasan dan mendirikan komunitas etnik tertentu.

Selanjutnya Mulyadi (Suminar, 2012) menyatakan bahwa nilai moral dan tradisi upacara adat membawa konsekuensi moral bagi masyarakat pendukungnya untuk tetap melestarikannya karena amanat leluhur yang harus dilaksanakan secara turun-temurun. Oleh karena itu, tradisi dan upacara adat merupakan seperangkat nilai intriksi kultural yang diyakini kebenarannya dan digunakan untuk mengatur dan menjaga kelestarian kehidupan kultural suatu masyarakat disebut ideologi kultural. Tradisi upacara adat terkadang simbol budaya masyarakat pelakunya yang cenderung menarik untuk dinikmati karena memiliki nilai estetika dan karakteristik tersendiri.

Keberadaan tradisi dan upacara adat penting bagi masyarakat pendukungnya. Tradisi dan upacara adat menjadi bermakna bagi pendukungnya diantaranya sebagai penolak balak. Dalam hal yang demikian, masyarakat merasa mempunyai kewajiban untuk menjaga dan melestarikannya. Oleh karena itu, tradisi dan upacara adat perlu dilakuakan oleh masyarakat pendukungnya secara berkelanjutan agar dapat terjaga sepanjang masa.

Kabupaten Ponorogo hanya memliki satu telaga. Keberadaan telaga tersebut menjadi tempat pariwisata yang paling menarik. Telaga tersebut dinamai Telaga Ngebel karena berada di Kecamatan Ngebel. Selain keindahan dan kesegaran udara telaga, tradisi upacara larungan merupakan salah satu faktor Telaga Ngebel sebagi tempat pariwisata domestik maupun mancanegara yang paling menarik di Kabupaten Ponorogo.

Masyarakat Ponorogo termasuk etnik Jawa, sehingga melaksanakan laku budaya tradisi Jawa semacam aktivitas yang dilakukan sebagai suatu simbolisasi keselarasan dan keseimbangan antara Jagad Gedhe dan Jagad Cilik. Pengertian Jagad gedhe yaitu semua lingkungan tempat manusia hidup dengan dengan Jagad Cilik yaitu diri dan batin manusia itu sendiri (Sumartono, 1996).

Masyarakat Ponorogo mayoritas masih melakukan tradisi dan melestarikan ajaran-ajaran leluhurnya. Upacara Larungan dilaksanakan setiap tanggal 1 Muharam (penanggalan Islam) atau 1 Suro (penanggalan Jawa). Upacara Larungan di Telaga Ngebel Kecamatan Ngebel Kabupaten Ponorogo merupakan salah satu tradisi peninggalan leluhur yang diwujudkan dengan melarungkan sesaji ke Telaga Ngebel. Oleh karena itu, dilakukan sebagai simbol ungkapan rasa terima kasih kepada Tuhan yang telah memberikan hasil bumi kepada masyarakat. Tradisi tersebut dilaksanakan setiap satu tahun sekali pada bulan suro.

Upacara Larungan Telaga Ngebel erat kaitannya dengan kehidupan sosial, ekonomi, dan agama masyarakat Ponorogo. Upacara larungan tersebut mengandung makna yang sangat mendalam, yaitu keyakinan jika tidak melakukannya maka terjadi malapetaka, yaitu air Telaga Ngebel meluap kemudian menenggelamkan masyarakat sekitarnya.

Keberadaan Larung $\begin{array}{r}\text { sesaji } \\ \text { ini mengalami gejolak, }\end{array}$ sehingga
menyebabkan ritual larungan beberapa
kali berganti nama antara lain larung sesaji
Telaga Ngebel, larung risalah doa Telaga
Ngebel dan yang terbaru adalah upacara


larungan Telaga Ngebel. Hal tersebut dipengaruhi dari sudut pandang bahwa Kabupaten Ponorogo termasuk kota santri karena memiliki banyak pondok pesantren yang berjumlah 62 pondok. Salah satu yang terkenal adalah Pondok Modern Darussalam Gontor yang juga menjadi pondok pesantren terbesar di Kabupaten Ponorogo (wikipedia: 2018). Oleh karena itu, istilah Larung Risalah Doa oleh sebagian masyarakat dianggap tidak relevan dengan ajaran Islam karena mengandung paham animisme dan dinamisme. Sesajian tersebut dipersembahkan kepada penguasa Telaga Ngebel dan pemberian sesaji keempat sudut telaga yang dianggap keramat.

Larung Sesaji sudah menjadi tradisi yang melekat pada masyarakat setempat. Melihat hal tersebut, maka perlu dilakukan penelitian dengan judul "Kearifan Lokal Upacara Larungan Telaga Ngebel dalam Membangun Harmonisasi Sosial pada Masyarakat Ngebel Kabupaten Ponorogo".

\section{Kearifan Lokal}

Bila dilihat dari aspek etimologisnya, pengertian kearifan lokal terdiri dari dua kata, yaitu kearifan (wisdom) dan lokal (local). Local berarti setempat, sementara wisdom sama dengan kebijaksanaan. Pengertian kearifan lokal merupakan gagasangagasan atau nilai-nilai, pandangan-pandangan setempat yang bersifat bijaksana, penuh kearifan, bernilai baik yang tertanam dan diikuti oleh seluruh anggota masyarakatnya (Suryono).

Menurut Mukti dan Winarna (Pramono 2014) kearian lokal (local wisdom) merupakan usaha manusia dengan menggunakan akal budinya (kognisi) untuk bertindak dan bersikap terhadap sesuatu objek atau peristiwa yang terjadi dalam ruang tertentu. Ciri kearifan lokal adalah tidak bersifat instan, melainkan berporos pada proses menuju kebaikan. Sebab itu, tidak berpretensi pada aplikasi semata yang kemudian menjadikannya sangat jauh dari hal yang bersifat instan, sehingga dalam kurun waktu lama menjadi cermin budaya bagi masyarakat. Inilah yang menjadikannya sebagai akar dan pedoman kehidupan yang turun temurun dan menjadi warisan komunitas atau bahkan suku bangsa dan bangsa.

Berdasarkan pendapat para ahli dapat disimpulkan mengenai beberapa pemaknaan kearifan lokal antara lain: (a) kearifan lokal merupakan kebenaran yang telah menjadi tradisi di suatu daerah, (b) kearifan lokal merupakan perpaduan nilai suci firman Tuhan dengan berbagai nilai yang ada di masyarakat, (c) kearifan lokal merupakan perwujudan keunggulan budaya masyarakat, (d) kearifan lokal merupakan produk budaya masa lalu yang terus dijadikan sebagai pegangan hidup.

Kearifan lokal dan keunggulan lokal merupakan kebijaksanaan manusia yang bersandar pada filosofi nilai-nilai, etika, cara-cara dan perilaku yang melembaga secara tradisional. Kearifan lokal adalah nilai yang dianggap baik dan benar sehingga dapat bertahan dalam waktu yang lama bahkan melembaga. Bentuk-bentuk kearifan lokal dalam masyarakat dapat berupa: nilai, norma, etika, kepercayaan, adat istiadat, hukum, adat, dan aturan-aturan khusus. Kearifan lokal hidup dalam aneka budaya masyarakat dengan fungsinya yang bermacam-macam pula (Suryono, 2012).

Menurut Suryono (2012) fungsi kearifan lokal antara lain:

a. Berfungsi untuk konservasi dan pelestarian sumber daya alam.

b. Berfungsi untuk pengembangan sumber daya manusia.

c. Berfungsi untuk pengembangan kebudayaan dan ilmu pengetahuan.

d. Berfungsi sebagai petuah, kepercayaan, sastra dan pantangan.

e. Bermakna sosial, misalnya upacara integrasi komunal atau kekerabatan dan pada upacara pertanian.

f. Bermakna etika dan moral, yang terwujud dalam upacara Ngaben dan selametan roh. 
g. Bermakna politik atau hubungan kekuasaan patro-client, dsb.

Kearifan lokal dapat juga dimaknai sebuah pemikiran tentang hidup yang dilandasi nalar jernih, budi yang baik, dan memuat hal-hal positif. Kearifan lokal dapat diterjemahkan sebagai karya akal budi, perasaan mendalam, tabiat, bentuk perangai, dan anjuran untuk kemuliaan manusia. Penguasaan atas kearifan lokal akan mengusung jiwa masyarakat semakin berbudi luhur.

\section{Upacara Larungan Telaga Ngebel}

Upacara larungan adalah ritual yang dilaksanakan oleh masyarakat di sekitar Telaga Ngebel Kabupaten Ponorogo dengan tujuan agar terhindar dari malapetaka. Berdasarkan keterangan dari masyarakat Ngebel bahwa sebelum dilaksanakan upacara larungan, Telaga Ngebel banyak memakan banyak korban jiwa. Mulai dari anak sekolah ketika mengadakan perkemahan di sekitar telaga tiba-tiba saja hilang dan ditemukan telah mengambang di atas telaga, mobil yang tiba-tiba terjun ke telaga dan mengakibatkan penumpangnya tewas.

Upacara larungan mula-mula dikenal dengan sebutan larung sesaji. Ritual larung sesaji ini mulai diadakan sejak tahun 1993. Pada waktu itu, yang menjabat sebagai Camat Ngebel adalah Bapak Winadi. Melihat banyaknya kejadian yang memakan korban jiwa, maka Bapak Winadi berinisatif untuk mengumpulkan para sesepuh desa dan para ulama untuk mencari solusi atas permasalahan tersebut. Akhirnya, tercetuslah suatu gagasan untuk mengadakan sebuah ritual demi memohon perlindungan keselamatan dari Tuhan Yang Maha Esa, agar Ngebel terbebas dari segala marabahaya dan petaka. Dalam pertemuan tersebut telah disepakati bahwa ritual larung sesaji akan di adakan pada malam 1 suro dalam penanggalan Jawa atau malam 1 Muharam. Diharapkan dengan ritual tersebut dapat menjauhkan Ngebel dari segala musibah dan bencana. Akhirnya ritual larung sesaji tersebut selalu diadakan secara rutin setiap tahunnya.

Sebagai kota santri yang hampir seluruh penduduknya beragama Islam, larung sesaji sudah menjadi tradisi yang melekat pada warga setempat. Pemerintah daerahsetempatkemudianmemodifikasinya dengan "Larung Risalah Doa". Dikatkan Larung Risalah Doa, dikarenakan pada saat larungan ikut ditenggelamkan juga kotak doa dari Kyai pondok pesantren Gontor Ponorogo. Namun beberapa pihak kurang setuju dan menganggap penamaan ritual tersebut tidak pas karena sejatinya doa itu dipanjatkan kepada Tuhan Yang Maha Kuasa dan bukannya dilarung ke telaga. Akhirnya berdasarkan kesepakatan bersama dan demi melestarikan tradisi leluhur, maka ritual tersebut berganti nama menjadi "Upacara Larungan 1 Suro Telaga Ngebel".

Upacara larungan termasuk upacara selamatan yang dilakukan di Telaga Ngebel. Ritual ini diawali dengan menyembelih seekor kambing kendhit (kambing berbulu coklat yang ada lingkaran putih atau hitam seperti sabuk di perutnya). Kendhit dijadikan sebagai lambang dari manusia yang suka menggumbar hawa nafsu. Sehingga dengan penyembelihan kambing kendhit ini, masyarakat Ngebel berharap agar dijauhkan dari sifat buruk seperti itu. Kepala kambing kendhit ini ditanam di dermaga telaga, kakinya ditanam pada empat sudut telaga bersama dengan sesaji yang lain, sedangkan dagingnya dibagikan kepada warga sekitar untuk sedekah.

Sesajian yang ikut dilarungkan pada saat ritual berlangsung adalah: (1) tumpeng bersama nasi golong 5 buah (nasi golong merupakan nasi putih yang dibungkus daun pisang dan di dalam nasi tersebut diisi telur ayam), (2) kacang panjang, (3) telur, (4) ayam panggang (berasal dari ayam yang berwarna merah mulus), (5) 
pisang raja setandhan, (6) dhupa/menyan, (7) takir cok bakal, (8) jenang merah putih, (9) pisang ambon, (10) jenang tolak balak, (11) separangkat alat penginangan (suruh, gambir, kapur, jambe, cengkeh), (12) jenang ketan, (13) bunga 7 rupa, (14) empat potong kaki kambing kendhit, (15) kepala kambing kendhit, dan (16) darah kambing kendhit yang telah ditampung di selembar kain putih.

Pelaksanaan upacara larungan dilaksanakan 2 kali, yaitu pada malam 1 Suro dan pagi harinya pada pukul 10.00 WIB. Sore menjelang malam 1 Suro, disepanjang jalan di Telaga Ngebel telah dipasangi obor sebagai penerangan jalan. Di kecamatan berkumpul 40 sesepuh dari Perkumpulan Ayu Mardi Utama (PAMU), mereka melakukan tirakatan. Ketika acara tersebut berlangsung mantra dengan kosakata Jawa dan Arab dibaca bersamasama.

Mantra yang dibaca pada prosesi tirakatan saat diadakan larungan adalah Mantra Urip Sejati, Mantra Sejatining Urip, Mantra Jumbuhe Kawula Gusti, Mantra Ingsun Urip Biso Mati, Mantra Nguri-uri. Kelima mantra tersebut mempunyai makna sebagai berikut (Suminar, 2012).

Pertama, mantra Urip Sejati mempunyai makna tentang kehidupan seseorang bayi, karena bayi adalah manusia yang masih suci belum mengetahui apapun yang telah terjadi. Seperti halnya bayi belum mengerti bahwa api itu panas dan jika lapar harus makna. Mantra tersebut menggambarkan fase perkembangan hidup manusia. Pada dasarnya perkembangan itu sama saja mulai dari bayi baru lahir hingga dewasa, yang membedakan hanyalah tingkah laku dan tingkat ketakwaannya.

Kedua, mantra Sejatining Urip mempunyai makna tentang kehidupan manusia dewasa, yaitu kehidupan yang sejati. Kehidupan manusia lahir hingga dewasa yang di dalamnya memuat bagaimana caranya untuk bisa hidup dengan mulia di jalan Allah.
Pada mantra Sejatining Urip dijelaskan tentang "dulur papat" yaitu empat rangkain yang tidak dapat dipisahkan dan harus dijaga kegunaannya. Adapun "dulur papat" tersebut adalah indera manusia yaitu penglihatan, pendengaran, penciuman, dan pengucapan.

Mantra Sejatining Urip juga menjelaskan tentang kehidupan bahwa manusia hendaklah idhep, madhep, mantep, tetep, dan enget. Mantra Sejatining Urip mengajarkan tentang kehidupan manusia hendaklah tidak mudah terpengaruh dengan orang lain, selalu percaya atas dirinya sendiri karena orang lain belum tentu benar dan menimbulkan fitnah.

Ketiga, mantra Jambuhe Kawula Gusti mempunyai makna agar manusia selalu mengingat Tuhannya dengan menyeimbangkan antara lahir dan batinnya. Upaya itu dapat dilakukan dengan menjaga segala kekayaan alam yang ada sebagai wujud syukur atas karunia yang telah diberikan Allah SWT.

Keempat, mantra Urip Biso Mati mengandung makna agar manusia selalu menjaga tingkah lakunya selama hidup di dunia. Semua amal baik yang baik dan buruk menentukan tempat di akhirat nanti. Pada dasarnya manusia dilahirkan dalam keadaan suci, sehingga apabila manusia telah tiba saatnya meninggal maka ia ada kematian maka ada juga kehidupan.

Kelima, mantra Nguri-uri mempunyai makna untuk mengajak manusia selalu beribadah kepada Tuhan-Nya. Ajakan tersebut dilakukan dengan menjaga kelima indera yang telah diberikan Allah SWT untuk berbuat kebaikan.

Setelah ritual tirakatan, para sesepuh mengelilingi telaga untuk menanam empat potongan kaki kambing di tempat-tempat yang dianggap keramat yaitu gua Bebong, gua Nyai Latung, gua Kumambang yang sekarang terendam air dan gua yang ada di tepi telaga sebagai tempat peristirahatan raja Brawijaya $\mathrm{V}$ dari kejaran musuh. 
Dalam waktu yang hampir bersamaan seorang yang bernama Sakun melarungkan sesajian ke tengah telaga.

Pagi harinya, pada tanggal 1 Suro atau 1 Muharram ritual larung kembali dilaksanakan. Ritual tersebut sebagi modifikasi yang dilakukan oleh pihak Pemerintah Daerah setempat. Dalam perkembangannya, larung sesaji yang penuh aroma ghaib menjadi kontroversi bagi masyarakat Ponorogo yang mayoritas beragama Islam. Oleh sebab itu, pemerintah akhirnya memodifikasinya dengan Larung Risalah Doa. Prosesi Larung Risalah Doa mirip dengan larung sesaji yang dilakukan pada malam hari. Perbedaannya ada pada jenis sesaji dan doa. Pada Larung Risalah Doa ukuran sesaji lebih besar. Sesaji tersebut terbuat dari beras dan bahan makanan lain. Larung Risalah Doa diperuntukkan bagi hewan penghuni telaga seperti ikan dan lainnya. Selain sesaji, ikut ditenggelamkan juga kotak berisi doa keselamatan yang telah ditulis oleh Kyai Pondok Pesantren Gontor ke dasar telaga. Doa ditujukan kepada Sang Pencipta yaitu Tuhan Yang Maha Esa dan kepada penguasa Telaga Ngebel yaitu Eyang Joko Tawang Tuntung Kawis (Baru Klinting). Tujuannya adalah meminta keselamatan dan perlindungan Tuhan. Bersamaan dengan tenggelamnya sesaji, maka berakhir pula ritual tahunan di Ngebel.

\section{Masyarakat}

Masyarakat (society) berasal dari kata Latin "socius" yang berarti persahabatan (companionship offiendship). Persahabatan berarti sosialisasi (sociability). Menurut George Simmel, sosialisasi menjadi unsur dasar masyarakat. Hal ini menunjukkan bahwa manusia selalu hidup dengan orang lain (Jacky, 2015:41).

Menurut Aristoteles, manusia adalah "binatang sosial" (social animal). Manusia membutuhkan masyarakat untuk hidup, bekerja dan menikmati hidup. Masyarakat telah menjadi syarat penting bagi kehidupan manusia untuk melanjutkan hidup. Secara definitif, masyarakat diartikan sebagai sekelompok orang yang dimiliki kesamaan budaya, menempati wilayah territorial tertentu dan memiliki perasaan untuk membentuk sebuah kesatuan. Inti dari masyarakat adalah interaksi timbalbalik (mutual interaktions) dan kertarikan (interrelations) individu dan kelompok (Jacky, 2015).

Berdasarkan definisi tersebutmenunjuk kan bahwa untuk dapat dikatakan sebagai masyarakat maka harus ada sekelompok manusia yang bertempat tinggal dan bekerja sama dalam suatu wilayah tertentu dan melakukan interaksi satu sama lain. Lebih lanjut ada beberapa definisi mengenai masyarakat yang telah dikemukakan oleh beberapa ahli.

Morris Ginsberg mendefinisikan masyarakat sebagai kumpulan individu yang disatukan oleh hubungan tertentu atau mode perilaku yang menandai mereka dari orang lain yang tidak masuk ke dalam hubungan atau yang berbeda dari mereka dalam perilaku (Jacky, 2015). Kemudian Ferdinand Tonnies mengartikan masyarakat (gesellschaft) sebagai asosiasi dimana hubungan yang terjadi impersonal, kontrak dan jangka pendek, individu termotivasi oleh kepentingan pribadi rasional (Jacky, 2015).

Menurut Koentjaraningrat (2009) masyarakat adalah sekumpulan manusia yang saling "bergaul", atau dengan istilah ilmiah, saling "berinteraksi". Masyarakat merupakan suatu kesatuan manusia dapat mempunyai prasarana agar warganya dapat saling berinteraksi. Whitaker (Jacky, 2015) menyatakan bahwa sosiolog menggunakan istilah masyarakat lebih sempit dari orang awam. Masyarakat merupakan agregrat (kumpulan) orang yang tinggal dalam satu wilayah tertentu, terdapat batas spesifik dan disatukan oleh kebudayaan tertentu. Agregat ini mengacu pada individu dan kelompok dari semua jenis. 
Berdasarkan definisi di atas dapat disimpulkan bahwa masyarakat merupakan kumpulan individu yang disatukan oleh hubungan tertentu yang bersifat kontinyu dan terkait oleh identitas bersama. Dalam hidup bermasyarakat, manusia selalu membutuhkan manusia lainnya agar dapat memenuhi segala kebutuhan hidupnya.

Menurut Jacky (2015) terdapat 10 karakteristik masyarakat yaitu sebagai berikut : (1) wilayah, (2) kolektifitas orang, (3) perasaan kelompok yang kuat, (4) interrelations individu dan kelompok, (5) interaksi timbal balik, (6) interaksi yang terlembagakan, (7) hubungan tertutup dan informal, (8) kesamaan budaya, (9) nilainilai umum dan keyakinan, (10) hubungan impersonal.

\section{Harmonisasi}

Harmoni (dalam bahasa Yunani: harmonia, berarti terikat secara serasi/ sesuai). Menurut bidang filsafat, harmoni adalah kerja sama antara berbagai faktor dengan sedemikian rupa hingga faktorfaktor tersebut dapat menghasilkan suatu kesatuan yang luhur. Sebagai contoh, seharusnya terdapat harmoni antara jiwa jasad seseorang manusia, kalau tidak, maka belum tentu orang itu dapat disebut sebagai satu pribadi. Pada bidang musik, sejak abad pertengahan pengertian harmoni tidak mengikuti pengetian yang pernah ada sebelumnya, harmoni tidak lagi menekankan pada urutan bunyi dan nada yang serasi, namun keserasian nada secara bersamaan. Singkatnya Harmoni adalah ketertiban alam dan prinsip/hukum alam semesta. Konsep harmoni yaitu (1) perbedaan antarunsur atau keragaman; (2) timbal balik; (3) menuju kesatuan yang luhur (Wikipedia, 2017).

Konteks untuk membandingkan antara mentalis Barat dan Timur, Soetoprawiro mengemukakan mengenai harmoni yang menjadi faktor paling penting di dalam kehidupan masyarakat Indonesia. "Segala sesuatu yang baik dapat di terjemahkan ke dalam istilah harmoni. Segala sesuatu hendaknya senantiasa serasi, selaras, seimbang. Yang adil dan makmur adalah harmonis. Segala perilaku dan tindaktanduk itu berangkat dari situasi yang harmonis menuju ke situasi yang harmonis baru" (Goesniandhie, 2006).

Berdasarkan beberapa pengertian di atas, istilah harmoni diartikan sebagai keselarasan, kesesuaian, kecocokan dan keseimbangan. Unsur-unsur yang dapat di tarik dari perumusan pengertian harmonisasi, antara lain (Goesniandhie, 2006): (a) Adanya hal-hal ketegangan yang berlebihan. (b) Menyelaraskan kedua rencana dengan menggunakan bagian masing-masing agar membentuk suatu sistem. (c) Suatu proses atau suatu upaya untuk merealisasi keselarasan, kesesuaian, kecocokan, dan keseimbangan. (d) Kerja sama antara berbagai faktor yang sedemikian rupa, hingga faktor-faktor tersebut menghasilkan kesatuan yang luhur.

Kamus Besar Bahasa Indonesia mengartikan harmoni yang berarti selaras atau serasi, sedangkan sosial berarti berkaitan dengan masyarakat, mengenai masyarakat atau suka memperhatikan kepentingan umum. Sedangkan menurut Enda M.C sosial adalah cara mengenai hubungan sosial antar individu secara baik dan saling menghargai satu dengan yang lain (Taufiq, 2014).

Harmoni sosial merupakan kondisi dimana individu hidup sejalan dan serasi dengan tujuan masyarakatnya dan masingmasing anggota masyarakat dapat menjalani hidup secara baik sesuai kodrat dan posisi sosialnya. Keharmonisan akan terwujud jika di dalamnya terdapat sikap saling menghargai dan menyayangi antar anggota keluarga atau masyarakat. Harmoni sosial akan terwujud apabila di dalam masyarakat tercipta kehidupan yang damai dan saling menghargai antar anggota masyarakat yang dapat hidup secara berdampingan meskipun memiliki perbedaan. 


\section{METODE}

Penelitian ini mengambil lokasi Desa Ngebel, Kecamatan Ngebel Kabupaten Ponorogo. Peneliti mengambil lokasi ini karena pelaku tradisi upacara larungan adalah masyarakat sekitar Telaga Ngebel. Masyarakat Ngebel sangat antusias dengan larungan yang di adakan setiap tanggal 1 Suro. Menurut persepsi masyarakat Ngebel, jika tidak melakukan upacara larungan mereka akan mendapat marabahaya. Selain itu, peneliti ingin megetahui bagaimana masyarakat Desa Ngebel yang mayoritas beragama islam menjalankan tradisi yang di wariskan turun temurun oleh leluhur mereka tersebut. Penelitian ini akan dilaksanakan selama enam minggu pada bulan Januari sampai dengan Maret 2018.

Pendekatan yang digunakan dalam penelitian ini adalah pendekatan kualitatif deskriptif. Pendekatan kualitatif digunakan dengan maksud menemukan dan memahami fakta yang tersembunyi dibalik fenomena yang terjadi di dalam masyarakat. Metode peneliti gunakan dalam penelitian ini adalah metode studi kasus. Kasus yang diamati peneliti berupa keharmonisasian masyarakat Desa Ngebel yang berkaitan dengan kearifan lokal dalam upacara larungan. Peneliti berupaya menggali data berupa pandangan narasumber yang kemudian peneliti akan mendeksripsikan harmonisasai masyarakat terutama saat upacara larungan Telaga Ngebel sesuai dengan keadaan di lapangan.

Sesuai dengan karakteristik yang diperlukan dalam penelitian ini, maka peneliti menggunakan teknik pengumpulan data yang meliputi:

\section{Observasi}

Menurut Sugiyono (2008), teknik pengumpulan data dengan observasi digunakan bila penelitian berkenaan dengan perilaku manusia, proses kerja, gejala-gejala alam dan bila responen yang diamati tidak terlalu besar. Observasi melibatkan dua komponen, yaitu pelaku observasi dan obyek yang diobservasi. Peneliti menggunakan observasi non partisipan dalam penelitian ini, dimana peneliti hanya mengamati secara langsung keadaan obyek, peneliti tidak aktif dan tidak ikut terlibat langsung.

\section{Wawancara}

Wawancara merupakan percakapan dengan maksud tertentu yang dilakukan oleh dua pihak, yaitu orang yang melakukan wawancara yang mengajukan pertanyaan, dan pihak yang diwawancara yang memberikan jawaban atas pertanyaan itu (Moleong, 2007). Penelitian ini menggunakan wawancara secara semi terstruktur. Sebelum melakukan wawancara, peneliti telah menyiapkan pertanyaanpertanyaan yang akan diajukan kepada informan. Namun, dalam pelaksanaannya akan disesuaikan dengan keadaan responden. Wawancara dilakukan peneliti dengan Kepala Desa Ngebel, tokoh masyarakat Desa Ngebel serta masyarakat Desa Ngebel.

\section{Dokumentasi}

Menurut Guba dan Lincoln (dalam Sugiyono, 2008) mendefinisikan dokumen ialah setiap bahan tertulis ataupun film. Dokumen sebagai sumber data dimanfaatkan untuk menguji, menafsirkan, bahkan untuk meramalkan (Sugiyono, 2008). Dokumentasi dilakukan dengan cara mengumpulkan dokumentasi pendukung data-data penelitian yang dibutuhkan sehingga dalam penelitian ini, peneliti menyelidiki benda-benda tertulis seperti catatan-catatan, arsip, dokumen pemerintah, foto-foto kegiatan, dan sebagainya.

Setelah data-data hasil pengamatan diperoleh maka selanjutnya dilakukan analisis data. Teknik analisis data dapat dilakukan pada saat pengumpulan data hingga selesainya pengumpulan data. Analisis data dilakukan untuk memperoleh informasi yang nantinya digunakan untuk menjawab pertanyaan peneliti. Dalam 
penelitian ini, peneliti menggunakan analisis data dengan model interaktif Miles dan Hubermen. Aktivitas dalam analisis data yaitu data reduction, data display, dan conclusion drawing/verification. Adapun langkah-langkah yang dilakukan peneliti sebagai berikut.

1. Reduksi data merupakan salah satu kegiatan berupa merangkum dan menafsirkan data untuk memperoleh gambaran tentang harmonisasi masyarakat dalam upacara larungan, sehingga data yang diperoleh lebih jelas dan mempermudah pengumpulan data selanjutnya.

2. Penyajian data yang digunakan oleh peneliti berupa deskripsi/uraian singkat. Deskripsi data digunakan untuk memperjelas informasi yang telah diperoleh.

3. Peneliti menarik kesimpulan dari hasil analisis data yang sudah dilakukan. Penarikan kesimpulan ini bertujuan untuk menjawab semua rumusan masalah yang telah dirumuskan sejak awal penelitian.

\section{HASIL DAN PEMBAHASAN \\ Partisipasi Masyarakat dalam Upacara Larungan Telaga Ngebel Kabupatan Ponorogo}

Acara larungan Telaga Ngebel merupakan adat turun temurun dari masyarakat Ngebel yang rutin dilaksanakan setiap tahunnya pada malam 1 Muharram atau 1 Suro. Acara larungan ini awal mulanya terbentuk berdasarkan hasil musyawarah yang dilakukan oleh pemerintah kecamatan bersama tokoh masyarakat Ngebel. Berdasarkan hasil musyawarah tersebut disepakati untuk melaksanakan larungan sebagai tolak balak karena seringnya terjadi musibah orang tenggelam disekitar Telaga Ngebel. Selain itu, acara larungan tersebut sebagai wujud rasa syukur kepada Tuhan YME atas berkah yang diberikan kepada masyarakat.
Acara larungan tersebut sudah diatur dari kecamatan Ngebel sehingga desa-desa yang ada hanya mengikutinya saja. Untuk persiapan acara larungan diadakan pertemuan atau musyawarah oleh pemerintah kecamatan Ngebel dengan tokoh masyarakat termasuk kepala desa. Seluruh masyarakat dilibatkan untuk meramaikan acara ini, namun tidak semua masyarakat terlibat dalam prosesi inti larungan, hanya yang sudah ditunjuk oleh panitia saja yang mengikutinya. Hal ini dikarenakan tidak semua masyarakat memiliki kemampuan untuk melaksanakan upacara tersebut. Upacara larungan ini masih kental dengan nuansa mistis sehingga biasanya hanya sesepuh-sesepuh desa yang memimpin upacaranya.

Partisipasi masyarakat merupakan wujud dukungan yang diberikan untuk tetap melestarikan tradisi tersebut. Peran serta masyarakat sangat penting demi suksesnya acara tersebut. Adapun bentuk partisipasi yang diberikan masyarakat dalam upacara larungan antara lain dengan mempersiapkan kebutuhan untuk acara larungan seperti membuat tumpeng, membersihkan telaga, membuat obor untuk acara obor 1000 pada malam 1 Suro atau 1 Muharram.

Hasil penelitian ini sejalan dengan pernyataan Arif (2012) bahwa partisipasi adalah suatu keterlibatan mental dan emosi seseorang atau kelompok masyarakat dalam situasi kelompok yang mendorong yang bersangkutan atas kehendak sendiri menurut kemampuan (swadaya) yang ada untuk mengambil bagian dalam usaha pencapaian tujuan bersama. Partisipasi atau turut ambil bagian tidak dihubungkan dengan sifat maupun keadaan sukarela atau tidak, maupun dipaksa atau tidak. Keikutsertaan yang disertai dengan ketertarikan dengan sesuatu secara sadar (Damsar dan Indrayani, 2016) 
Kearifan Lokal Upacara Larungan Telaga Ngebel Dapat Mewujudkan Harmonisasi Sosial Masyarakat

Kearifan lokal merupakan bagian dari budaya masyarakat yang tidak dapat dipisahkan dari kehidupan masyarakat itu sendiri. Kearifan lokal larungan yang telah menjadi budaya masyarakat Ngebel dikenal oleh masyarakat sejak dahulu. Kearifan lokal ini tetap dilestarikan hingga kini meskipun telah beberapa kali berganti nama namun tidak mempengaruhi makna dan kesakralannya bagi masyarakat Ngebel. Menurut Naritoom (Wagiran, 2012) menyiratkan beberapa konsep tentang kearifan lokal, yaitu: (1) kearifan lokal adalah sebuah pengalaman panjang, yang diendapkan sebagai petunjuk perilaku seseorang; (2) kearifan lokal tidak lepas dari lingkungan pemiliknya; dan (3) kearifan lokal itu bersifat dinamis, lentur, terbuka, dan senantiasa menyesuaikan dengan zamannya.

Upacara larungan yang dilaksanakan di Telaga Ngebel setiap tanggal 1 Suro erat kaitannya dengan kepercayaan masyarakat setempat tentang adanya malapetaka apabila tidak melakasanakannya. Kearifan lokal merupakan gagasan-gagasan atau nilainilai, pandangan-pandangan setempat yang bersifat bijaksana, penuh kearifan, bernilai baik yang tertanam dan diikuti oleh seluruh anggota masyarakatnya (Suryono, 2012). Masyarakat Ngebel menjadikan larungan ini sebagai wujud rasa syukur atas karunia yang diberikan serta sebagai tolak balak agar masyarakat Ngebel senantiasa diberikan ketentraman oleh Alloh SWT.

Nilai kearifan lokal yang terkandung dalam upacara larungan antara lain nilai religi, nilai hiburan, nilai kekerabatan, nilai keindahan dan nilai simbolik. Nilai religi diwujudkan dengan diadakannya kenduri oleh masyarakat dengan tujuan mengucap syukur kepada Tuhan Yang Maha Kuasa. Nilai hiburan yaitu dalam upacara larungan juga diadakan kegiatan lain seperti pagelaran karawitan, gelar reog, gelar tari, dll yang masih satu rangkaian acara dalam perayaan larungan Telaga Ngebel. Nilai kekerabatan yang terlihat dari kekompakan masyarakat dalam melaksanakan prosesi Larungan ini. Semua bekerjasama melaksanakan upacara yang dianggap sakral oleh masyarakat setempat. Selain itu terdapat nilai keindahan yang tercermin dalam pembuatan sesaji dari hasil bumi yang disusun rapi serta nilai simbolik dari setiap isi persembahan sesaji yang setiap bagiannya memiliki makna dan tujuan tersendiri.

Upacara larungan ini mengandung nilai-nilai solidaritas dan kerjasama. Hal ini dibuktikan dengan adanya gotong royong dalam mempersiapkan acara larungan tersebut. Masyarakat terbiasa untuk guyub dan saling toleransi yang dibuktikan dengan tidak adanya pertikaian atau perpecahan pada saat dilaksanakannya upacara larungan. Prinsipprinsip toleransi, kebebasan, keberagaman budaya, serta saling menghormati juga terkandung dalam larungan ini. Hal ini terlihat saat dilaksanakannya upacara larungan, masyarakat dari unsur kejawen seperti sesespuh-sesepuh desa mengadakan doa-doa di pendopo kecamatan, dari unsur-unsur islam seperti para kyai-kyai juga melaksanakan istighosah serta tahlil di masjid. Semua dapat berjalan beriringan tanpa ada konflik yang terjadi.

Kearifan lokal dapat digunakan sebagai acuan masyarakat dalam berperilaku dan menjadi filter kultural masyarakat dalam menjaga ikatan sosial. Malik dalam Fajriyah, Wayan dan Halin (2017) menyatakan bahwa kearifan lokal merupakan modal sosial potensial yang dimiliki oleh masyarakat untuk diaktualisasikan dalam resolusi konflik. Hal ini berarti bahwa kearifan lokal dapat dimanfaatkan bukan hanya sebagai panduan dalam interaksi sosial masyarakat tapi juga dalam mewujudkan perdamaian dan harmoni sosial. Gagasan-gagasan kearifan, kebijaksanaan, dan kebaikan yang terkandung dalam kearifan lokal dapat 
menjadi modal bagi masyarakat untuk mencegah konflik yang mungkin muncul dari hubungan sosial. Pencegahan konflik melalui pendekatan tradisional biasanya segera fokus pada dinamika konflik dan intervensi yang dilakukan seharusnya mampu mengindentifikasi ketidakpuasan, baik yang bersifat laten maupun telah menimbulkan ketegangan dan berpotensi meledakkan konflik.

Upacara larungan yang merupakan kearifan lokal masyarakat Ngebel mengandung nilai-nilai solidaritas, kerjasama, toleransi serta saling menghormati. Persaudaraan yang erat antar masyarakat dapat dilihat ketika pelaksanaan upacara larungan, meskipun dengan kepercayaan yang berbeda tapi masyarakat tetap saling tolong menolong dan gotong royong. Kegiatan ini menjadi wujud dari rasa persaudaraan yang dapat memperkuat solidaritas masyarakat.

\section{Peran Pemerintah Desa Ngebel dalam Mencegah Konflik dengan Menanfaatkan Kearifan Lokal Upacara Larungan Telaga Ngebel}

Mayoritas masyarakat Ngebel masih memegang teguh adat dan budaya yang dimilikinya. Adat istiadat memegang peran penting bagi kehidupan masyarakat. Adanya adat tersebut menjadikan masyarakat memiliki pedoman untuk menyelesaikan persoalan yang timbul di masyarakat. Nilainilai adat istiadat seperti ramah tamah, gotong royong dan musyawarah inilah yang memperkuat solidaritas masyarakat.

Pemerintah desa berkewajiban menjaga keamanan dan ketertiban warga untuk menciptakan lingkungan yang nyaman dan kondusif. Menurut Permen No 113 tahun 2014 Pemerintahan Desa adalah penyelenggaraan urusan pemerintahan dan kepentingan masyarakat setempat dalam sistem pemerintahan Negara Kesatuan Republik Indonesia. Pemerintah Desa adalah kepala Desa atau yang disebut dengan nama lain dibantu Perangkat Desa sebagai unsur penyelenggara pemerintahan desa. Pemerintah desa diharapakan dapat menanggulangi konflik yang terjadi di masyarakat agar tetap terkendali sehingga tidak sampai terjadi perpecahan antar warga.

Menurut Salimin (2015) secara garis besar ada delapan strategi penanggulangan konflik yaitu 1) pemecahan persoalan, 2) musyawarah, 3) mencari lawan yang sama, 4) mensub organisasikan kepentingan dan tujuan pihak-pihak yang sedang konflik kepada kepentingan dan tujuan yang lebih tinggi, 5) peningkatan interaksi dan komunikasi, 6) latihan kepekaan, 7) meminta bantuan kepada pihak ketiga, 8) koordinasi.

Kearifan lokal larungan yang merupakan warisan budaya leluhur yang berakar dari budaya lokal masyarakat memegang peranan penting dalam kehidupan masyarakat. Larungan sebagai kearifan lokal memiliki kekuatan untuk menumbuhkan rasa persatuan pada desa sehingga masyarakat dapat hidup berdampingan meskipun memiliki latar belakang dan kepercayaan yang berbeda.

Nilai-nilai kearifan lokal yang terdapat dalam larungan ini dimanfaatkan pemerintah desa bersama stakeholder untuk menggandeng tokoh-tokoh agama untuk bersama-sama menonjolkan persatuan kepada masyarakat sehingga membuat mereka bertahan dari ancaman konflik dan harmoni sosial tetap terjaga. Stakeholder menjadi aktor penting yang dapat merumuskan strategi pencegahan konflik agar konflik yang terjadi tidak berdampak lebih buruk lagi.

\section{SIMPULAN}

Berdasarkan hasil penelitian yang berkenaan dengan Kearifan Lokal Upacara Larungan Telaga Ngebel dalam Membangun Harmonisasi Sosial Pada Masyarakat Ngebel Kabupaten Ponorogo, maka dapat ditarik kesimpulan sebagai berikut: Partisipasi masyarakat di Desa Ngebel dalam upacara 
larungan yang dilaksanakan setiap tanggal 1 Muharram atau 1 Suro sudah berjalan dengan baik. Seluruh masyarakat memberikan kontribusinya sesuai dengan kemampuan dan kapasitasnya masingmasing seperti membuat tumpeng, kerja bakti membersihkan telaga serta membuat obor. Acara ini berjalan sesuai dengan arahan dari muspika kecamatan Ngebel selaku panitia pelaksana kegiatan, sehingga masyarakat umumnya hanya mengikuti rangkaian kegiatan yang sudah di rencanakan.

Kearifan lokal larungan merupakan tradisi turun temurun yang dilakukan masyarakat Ngebel dengan tujuan sebagai wujud rasa syukur kepada Tuhan YME serta sebagai tolak balak agar masyarakat Ngebel senantiasa diberi ketentraman. Nilai-nilai kearifan lokal yang terkandung dalam upacara larungan antara lain: nilai religi, nilai hiburan, nilai kekerabatan, nilai keindahan dan nilai simbolik. Pelaksanaan tradisi ini dapat menumbuhkan rasa toleransi, kebebasan, serta saling menghormati antarmasyarakat. Haltersebut dapat terlihat dari sikap masyarakat yang mau menerima perbedaan dan memiliki sikap toleransi, sehingga memperkuat persaudaraan antar warga. Masyarakat bebas memilih dalam menyambut tanggal 1 Suro atau 1 Muharram ini sesuai kepercayaan masing-masing. Masyarakat yang masih memegang teguh adat jawa atau dikenal dengan istilah kejawen akan berkumpul dan melakukan doa bersama di pendopo kecamatan. Sedangkan masyarakat dari golongan kyai dan ulama akan berkumpul untuk melakukan istigosah di masjid. Dengan demikian antara adat dan agama tetap berjalan seimbang, sehingga rasa persaudaraan semakin kuat. Hal tersebut menjadikan masyarakat senantiasa hidup secara damai dan harmonis karena tidak ada pertentangan di masyarakat.

Pemerintah berkewajiban memberikan rasa aman dan nyaman kepada masyarakat dalam kehidupan berbangsa dan bernegara. Upacara larungan sebagai kearifan lokal memiliki kekuatan untuk menumbuhkan rasa persatuan pada desa, sehingga masyarakat dapat hidup berdampingan meskipun memiliki latar belakang dan kepercayaan yang berbeda. Dalam upaya penyelesaian konflik yang terjadi, pemerintah desa mengandeng stakeholders yang ada untuk bersama-sama memecahkan konflik tersebut dengan menonjolkan persatuan kepada masyarakat.

Berdasarkan analisis dan kesimpulan tersebut, maka peneliti menyampaikan saran-saran sebagai berikut: Masyarakat Desa Ngebel diharapkan untuk terus mengembangkan, melestarikan dan mempertahankan tradisi upacara larungan Telaga Ngebel ini dan diturunkan kepada generasi selanjutnya.

Pemerintah diharapkan terus memberikan sosialisasi kepada masyarakat khususnya yang tidak setuju dengan larungan ini, dengan harapan masyarakat dapat mengambil sisi positif dari pelaksanaan larungan ini. Pemerintah desa dan masyarakat diharapkan bekerjasama dalam menjaga lingkungan Desa Ngebel agar tetap damai dan harmonis.

\section{DAFTAR PUSTAKA}

Arif, Saiful. 2012. Partisipasi, Demokrsi dan PembangunandalamartikelPartisipasi Warga dalam Pembangunan dan Demokrasi. Malang: Program Sekolah Demokrasi hlm 45.

Damsar dan Indrayani. 2016. Pengantar Sosiologi Perdesaan. Jakarta: Prenadamedia Group.

Fajriyah, Isrotul, Letjen TNI I Wayan Midhio dan Supandi Halim. 2017. Pembangunan Perdamaian Dan Harmoni Sosial di Bali Melalui Kearifan Lokal Menyama Braya. Jurnal Damai dan Resolusi Konflik, 3 (1). 
Goesniadhie, Kusnu. 2006. Harmonisasi Hukum dalam Perspektif Perundangundangan: Lex Spesialis Suatu Masalah.. Surabaya: JP Books.

Jacky, M. 2015. Sosiologi Konsep, Teori, dan Metode. Jakarta: Mitra Wacana Media.

Koentjaraningrat. 2009. Pengantar Ilmu Antropologi (Cetakan 9). Jakarta: Rieneka Cipta.

Kontributor Wikipedia, "Harmoni," Wikipedia, Ensiklopedia Bebas, https://id.wikipedia. org $/$ w/index.php?title=Harmoni\& oldid $=13351938$ (diakses pada 16 Desember 2017).

Kontributor Wikipedia, "Kabupaten Ponorogo," Wikipedia, Ensiklopedia Bebas, https://id.wikipedia.org/w/ index.php?title =Kabupaten Ponorogo\&oldid=13794982 (diakses pada 10 April 2018).

Moeleong, Lexy J. 2014. Metodologi Penelitian Kualitatif (Cetakan 32). Bandung: Remaja Rosdakarya.

Mulyadi. 2012. Konflik Sosial Ditinjau dari Segi Struktur dan Fungsi. Jurnal Humaniora, 14 (3).
Sugiyono. 2008. Metode Penelitian Kuantitatif, Kualitatif dan $R$ \& $D$ (Cetakan 4). Bandung: Penerbit Alfabeta.

Sumartono, H. 1995. Upacara Adat Larung Sesaji di Komunitas Nelayan Puger Kabupaten Jember. Jember: Lembaga Penelitian Kabupaten Jember.

Suminar, Istian Andra. 2012. "Kajian Struktur, Formula, dan Fungsi Mantra Ritual Larung Risalah Doa di Kabupaten Ponorogo". Skrispi. Fakultas Sastra Universitas Jember.

Suryono, Agus. 2012. Birokrasi dan Kearifan Lokal. Malang: UB Press.

Taufiq, Amal. 2014. "Adaptasi Budaya dan Harmoni Sosial: Proses Adaptasi Malaysia di Surabaya". Skripsi. Fakultas Sosial Politik UIN Sunan Ampel.

Wagiran. 2012. Pengembangan Karakter Berbasis Kearifan Lokal Hameayu Hayuning Buwana (Identifikasi Nilainilai Karakter Berbasis Budaya). Jurnal Pendidikan Karakter, 3 (2):111. 